Article

\title{
The Damage Assessment of Flood Risk Transfer Effect on Surrounding Areas Arising from the Land Development in Tainan, Taiwan
}

\author{
Song-Yue Yang ${ }^{1}{ }^{(\mathbb{D}}$, Ming-Hsiu Chan ${ }^{1, *}$, Che-Hao Chang ${ }^{2}$ and Ling-Fang Chang ${ }^{3}$ \\ 1 Water Resources Planning Institute, Water Resources Agency, Ministry of Economic Affairs, Taichung 41350, \\ Taiwan; acton0910@gmail.com \\ 2 Department of Civil Engineering, National Taipei University of Technology, Taipei 10608, Taiwan; \\ fencerc@gmail.com \\ 3 Agricultural Engineering Research Center, Taoyuan 32061, Taiwan; changlf@aerc.org.tw \\ * Correspondence: meanshow@gmail.com; Tel.: +886-4-2330-1466
}

Received: 28 February 2018; Accepted: 10 April 2018; Published: 12 April 2018

\begin{abstract}
The development with filling method might increase the flood risk and damage in the surrounding areas, especially in low-lying areas. The objective of this study was to develop a methodology to assess the damage of flood risk transfer effect on surrounding areas. We studied a development located in Tainan, Taiwan and applied a SOBEK model to analyze the transfer effect of flood risk, and calculated the amount of loss in the surrounding land. After land development, the risk of flooding in the development zone declined. However, the risk of flooding in the southern area of the development zone increased. The development of land changed the original decentralized drainage system to centralized drainage system. The peak outflow discharge of surface runoff increased so much that it was more than the flow capacity of the downstream channel. This resulted in transferring the flood risk to the surrounding areas. Direct losses due to floods for industrial, commercial, residential, and agricultural lands as well as public facilities were calculated by the flood damage curves. Indirect losses were estimated using the industry-related model. The expected annual damages before and after land development in the southern area of the development zone were NT\$ 6.38 million and NT\$ 7.39 million, showing that the expected annual damage was increased by NT\$ 1.01 million after land development.
\end{abstract}

Keywords: damage assessment; lowland; flood risk; SOBEK

\section{Introduction}

Many researchers have studied the relationship between the urbanization in the watershed and the hydrological regime in the river. In the process of urbanization, human interference in the natural hydrological cycle often increases the proportion of surface impermeable area and, as a result, there has been a decrease in the amount of infiltration and an increase in the amount of surface runoff [1-3]. In addition, owing to the reduction of surface vegetation and the channelization of the flow path, the concentration time is shortened, resulting in an increase in the peak flow of a river [4-7]. The flood risk downstream increases due to the urbanization in the watershed [8].

Du et al. indicated that the land-use changes in the Pearl River Delta (PRD), China, has markedly increased direct runoff over the past 20 years. Urbanization in PRD not only increased the area of impervious surfaces in the central plain, but also displaced farmland to the hilly peripheral areas [9]. Yao et al. used the Storm Water Management Model (SWMM) to analyze a typical urban residential catchment in Beijing, China. The results indicated that total impervious area (TIA) serves a more 
important role than directly connected impervious area (DCIA) in acting as a dominate factor affecting total runoff, and DCIA is more likely to affect runoff lag time [10]. Note that this problem may happen in other urban areas. Miller et al. investigated the change of runoff due to the transformation of previously rural landscapes into peri-urban areas in two adjacent catchments located within the town of Swindon in the United Kingdom. The result showed that the area with storm drainage has more influence on storm runoff response than either impervious area or development type [11]. To avoid the increased flood risk arising from land development, many countries, such as the U.S. [12,13], UK [14], etc., have requested developers to construct a detention basin to eliminate the increased peak flow caused by land development. In Taiwan, if the area of land development is more than two hectares, a detention basin must be built and a drainage plan must be submitted to the authority for review [15]. The detention basin is the most common engineering method used for runoff mitigation in the land development zone. Detention basins are designed for peak flow reductions during extreme rainfall events. In recent years, Low Impact Development (LID) methods, including porous pavement, bio-retention cell, rain barrel, infiltration trench, vegetation swale, etc., have been used for runoff volume reductions [16].

Those above studies mainly investigated a general phenomenon: urbanization in a watershed increases the surface runoff volume and peak flow rate. However, another seldom mentioned factor is the flood risk transfer effect from the land development activity with filling method in flood-prone lowlands. Tainan is a coastal city invaded frequently by typhoons, resulting in flooding and storm-surge $[17,18]$. Recently, the development activities have brought prosperity to coastal areas due to urbanization. Yang et al. took the Heshunliao Farm in Tainan, Taiwan as study object to assess the phenomenon and indicated the process of urban expansion has transformed farmland to construction land, resulting in the disappearance of original flood storage space. Detention basins should be built within the development zone to avoid the increased peak flow rate of the rivers and reduce flood risk. However, flood risk of the surrounding area near the development zone may increase due to the disappearance of the original flood storage space [19]. However, the damage assessment of flood risk transfer effect on the surrounding areas has not been mentioned before.

It is argued that economic losses may be estimated through hydrologic, hydraulic and disaster assessment models [20]. The models first simulate hydrologic events for several return periods and then calculate flooding area as well as depth through a hydraulic model. The disaster loss of various return periods can be estimated with the aid of the damage-frequency curves. The expected annual damage (EAD) is then obtained [21,22]. Flooding loss has been recently classified into direct and indirect loss [23-25], so that the sum of direct and indirect loss would be the amount of real loss. Flooding loss is estimated by two methods, which are the average method and the flood depth-damage curve method [26]. The flood depth-damage curve method can be further split into two types: questionnaire method and synthetic curve method [27]. There are two main approaches to estimate indirect losses, one is a certain percentage of direct losses [28] and the other is the input-output model in applied economics to estimate the indirect loss value [29]. The Flood Damage Assessment System developed by the Water Resources Planning Institute (WRPI), Water Resources Agency in Taiwan [30,31] aims to calculate the amount of loss in the flooded area in a systematical way and to spatially present area damage conditions as a reference for decision-making assessment.

The objective of this study was to develop a methodology to assess the damage of flood risk transfer effect on surrounding areas. The development project of Caohu Urban Land Readjustment Implementation [32] in Annan District of Tainan City, Taiwan was studied as an example. The paper is organized as follows: Section 2 describes the study area and the methodology. Section 3 presents and discusses the results obtained using the proposed methodology. Section 4 gives the final remarks on the potential usefulness of the approach. 


\section{Materials and Methods}

\subsection{Study Area}

The study area covers a territory of about 47.3 hectares with a width from east to west of about $1133 \mathrm{~m}$, and a length from north to south of about $730 \mathrm{~m}\left(120^{\circ} 12^{\prime} 00^{\prime \prime} \mathrm{E}, 23^{\circ} 2^{\prime} 10^{\prime \prime} \mathrm{N}\right)$. The terrain of the region is flat and low, and surface elevation range about 0.4 to $3.4 \mathrm{~m}$ (as shown in Figure 1). Except for some buildings, most of this area before development is fish farms. Surface runoff is discharged through the four drainage channels into the Yanshuixi Drainage. Drainage A is first discharged into Rainwater Sewer I, and is then discharged into the Yanshuixi Drainage. Drainage B is directly expelled into Yanshuixi Drainage. Drainage C is first discharged into Rainwater Sewer II, and then disembogued into Yanshuixi Drainage through Drainage F. Drainage D is first discharged into Drainage F, and then into Yanshuixi Drainage. The southern area of the development zone is 39.2 hectares, and land utilization is likely dominated by fish farms.

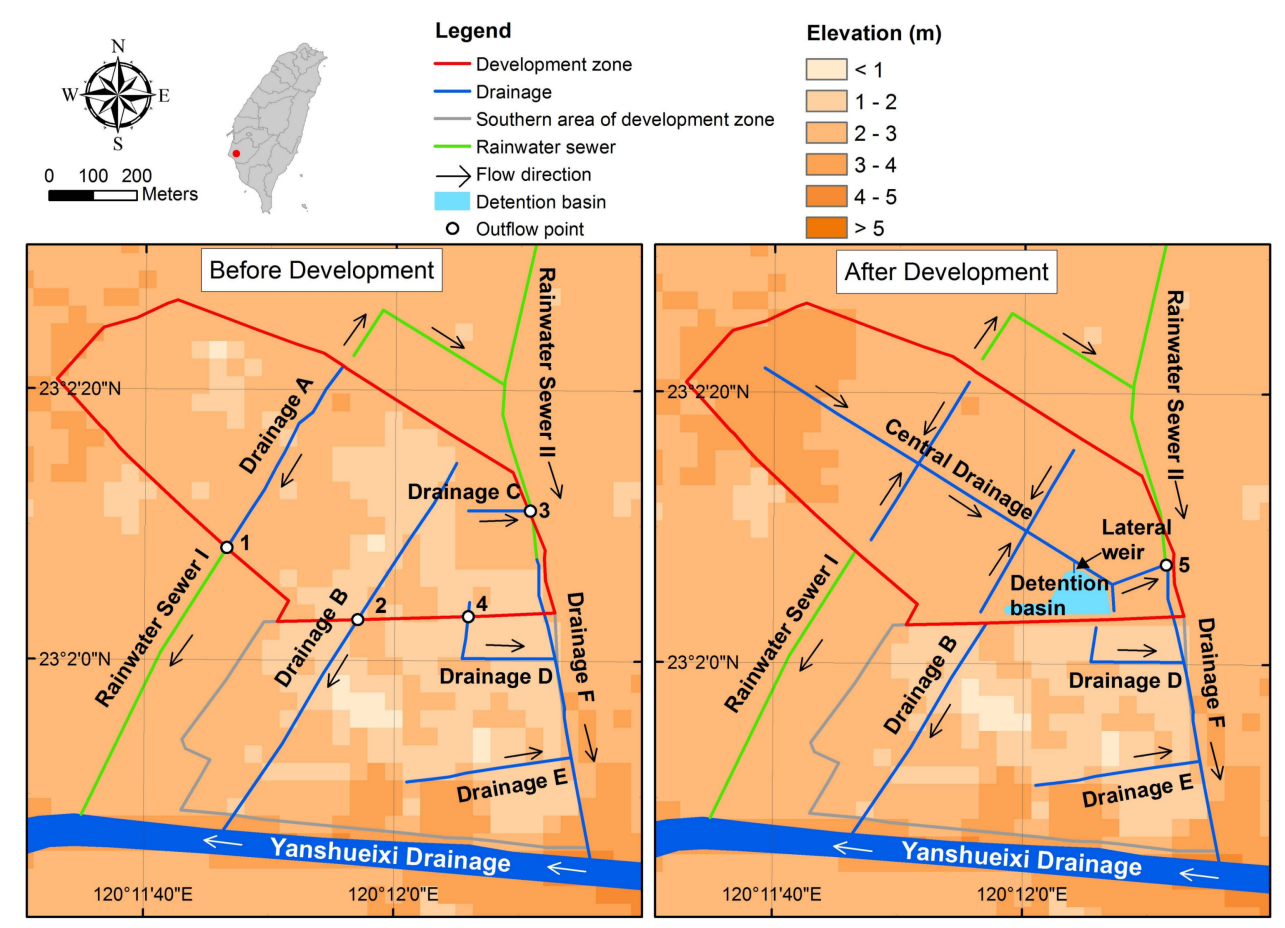

Figure 1. The maps of the study area before and after land development.

Land development would make this territory suitable for building residential houses, roads, parks, public facilities, etc. In the development zone, the filling method would be used to raise the surface elevation to about $2.63-3.37 \mathrm{~m}$. The land use in the southern area of the development zone would still be maintained (see Figure 1). The surface runoff in the development zone would be collected through drainages and then drained into Yanshuixi Drainage. To reduce the increased surface runoff due to land development, the runoff in drainages would be diverted to an off-stream detention basin through a lateral weir (at $\mathrm{W} \times \mathrm{H} \times \mathrm{L}$ of $12 \mathrm{~m} \times 1.2 \mathrm{~m} \times 24.1 \mathrm{~m}$ ) before draining out of the development zone. The volume of the detention basin is of $22,740 \mathrm{~m}^{3}$. The water in detention basin would drain through two culverts ( $80 \mathrm{~cm}$ in diameter) at the detention basin exit. The flow chart of the methodology in this study area is shown in Figure 2. 


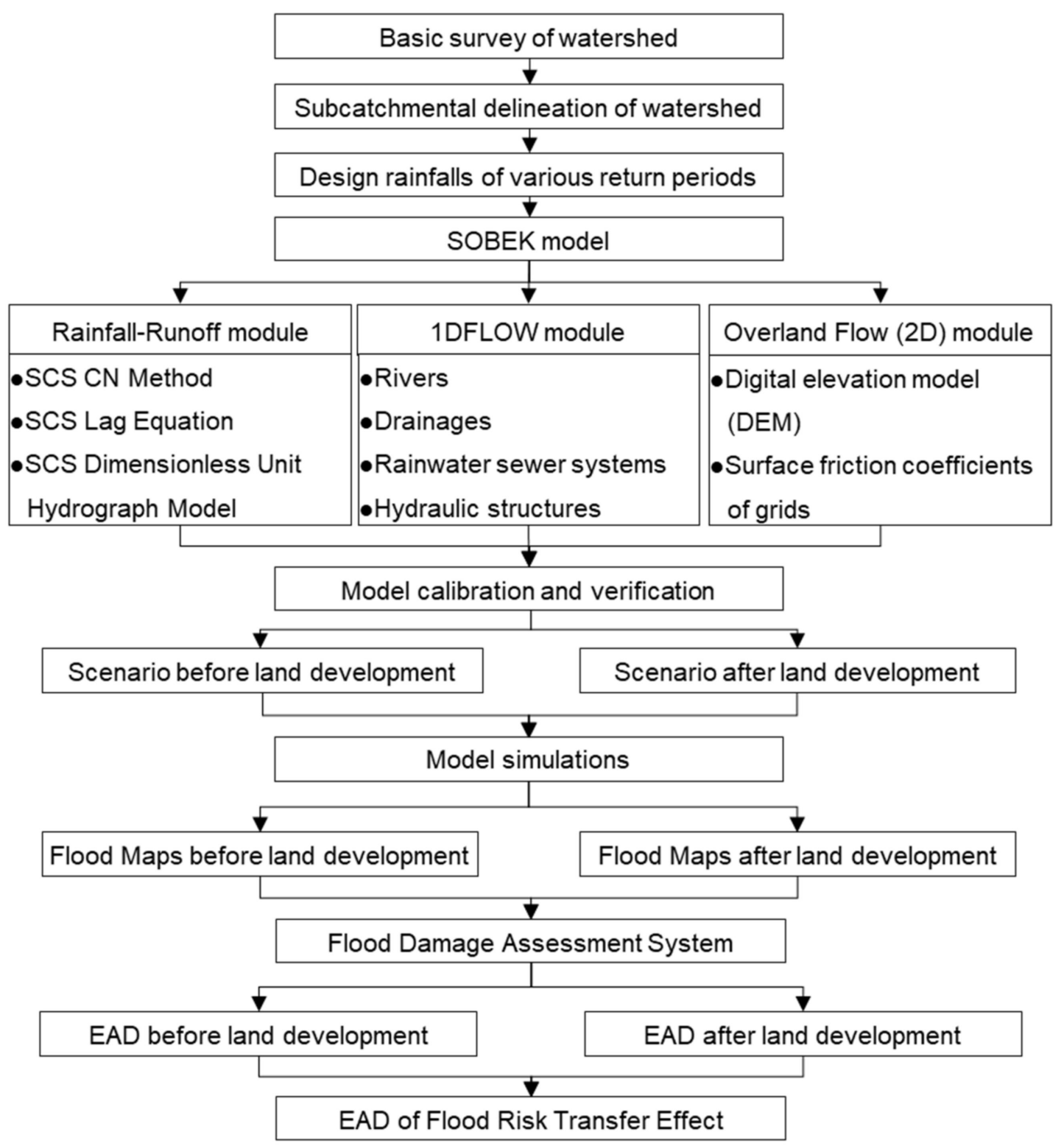

Figure 2. The flow chart of the methodology (modified from Yang et al. [19]).

\subsection{Design Rainfall}

According to the calculation method enacted by the Water Resources Agency, Ministry of Economic Affairs (MOEA), 24-h duration rainfall was adapted for design rainfall [33]. The 24-h rainfall amounts under various return periods are from the Yanshuixi Drainage Planning Report [34], as shown in Table 1. The design hyetographs were developed by alternating block method. The precipitation depths occurring in 144 successive time intervals of duration (10 $\mathrm{min}$ ) were specified over a total duration (24 h) [35]. In this study, the Horner's equation (intensity-duraton-frequency (IDF)) was used as follows:

$$
I_{t}^{T}=\frac{a}{(t+b)^{c}}
$$

where $I_{t}^{T}$ is the average rainfall intensity $(\mathrm{mm} / \mathrm{hr})$ in $t$ hours rainfall duration in $T$-year return period; and $a, b$ and $c$ are the regression coefficients, as shown in Table 1 . 
Table 1. The total rainfalls of 24-h duration and the regression coefficients of Horner's equation of various return periods.

\begin{tabular}{ccccc}
\hline Return Period (Year) & Total Rainfall (mm) & $\boldsymbol{a}$ & $\boldsymbol{b}$ & $\boldsymbol{c}$ \\
\hline 2 & 170 & 806.957 & 14.788 & 0.6114 \\
5 & 238 & 934.586 & 15.261 & 0.5796 \\
10 & 283 & 1091.991 & 19.353 & 0.5752 \\
25 & 340 & 1225.980 & 19.804 & 0.5643 \\
50 & 382 & 1331.362 & 20.177 & 0.5584 \\
100 & 424 & 1431.950 & 20.320 & 0.5532 \\
\hline
\end{tabular}

\subsection{Floodplain and Run-Off Modeling}

This study adopted the SOBEK model (version 2.13), developed by Deltares for hydrological and hydraulic analysis [36]. The SOBEK modules, including Rainfall-Runoff, 1DFLOW, and Overland Flow (2D), were used in this study. For Rainfall-Runoff module, the rainfall abstractions were calculated by the US Soil Conservation Service Curve Number (SCS CN) Method. The lag time was calculated by the SCS Lag Equation. The discharges were calculated by the SCS Dimensionless unit hydrograph. According to the Yanshuixi Drainage planning report [34], the soil type of the development zone was type $\mathrm{B}$, and the type of antecedent moisture condition (AMC) was type II. Before and after land development, the CN values were 66.77, and 83.24, respectively. The SCS CN Method, described as follows, was used to calculated the abstraction and the equations are the following:

$$
\begin{gathered}
P_{e}=\frac{(P-0.2 S)^{2}}{P+0.8 S} \\
S=25.4\left(\frac{1000}{C N}-10\right)
\end{gathered}
$$

where $P_{e}$ is the rainfall excess $(\mathrm{mm}) ; P$ is the depth of precipitation $(\mathrm{mm}) ; S$ is the potential maximum retention (mm); and $C N$ is the curve number.

Lag time was calculated according to SCS Lag Equation, shown as follows:

$$
\begin{aligned}
& T_{\text {lag }}=L^{0.8} \frac{(S+25.4)^{0.7}}{4238 \cdot H^{0.5}} \\
& \mathrm{~S}=25.4\left(\frac{1000}{C N}-10\right)
\end{aligned}
$$

where $T_{\text {lag }}$ is the lag time (h); $L$ is the length of the longest drainage path (m); and $H$ is the average watershed slope (\%).

The SCS Dimensionless Unit Hydrograph Model used as Rainfall-Runoff model was adapted to calculate the discharge and they are:

$$
\begin{gathered}
T_{\text {lag }}=0.6 T_{c} \\
T_{p}=\frac{T_{r}}{2}+T_{\text {lag }} \\
T_{b}=2.67 \times T_{p} \\
Q_{p}=\frac{0.208 A R}{T_{p}}
\end{gathered}
$$

where $T_{\text {lag }}$ is the lag time of peak flow (h); $T_{c}$ is the time of concentration (h); $T_{p}$ is the time to peak flow (h); $T_{r}$ is recession limb time (h); $T_{b}$ is the runoff time base (h); $Q_{p}$ is the peak flow (cms); $A$ is the area of catchment $\left(\mathrm{km}^{2}\right)$; and $R$ is the effective rainfall $(\mathrm{mm})$. 
For hydraulic analysis, the water flow is computed by solving the complete De Saint Venant equations. For one- and two-dimensional flow, continuity and momentum equations are solved numerically using the Delft-scheme. The SOBEK model can integrate rivers, drainages, rainwater sewer systems, and hydraulic structures such as gates, pumping stations, detention basins, etc. The computational grid resolution used in this study was $40 \mathrm{~m} \times 40 \mathrm{~m}$. The friction coefficients of channels in the model were determined according to their types. The digital elevation model (DEM) was drawn up according to the topography of the Yanshuei River watershed, and the resolution of the computational grid used was $40 \mathrm{~m} \times 40 \mathrm{~m}$. The surface friction coefficients of grids were determined according to the types of land uses. The model has been calibrated and verified by two precipitation events, Typhoon Megi on 27 September 2016 and Storm 0611 on 11 June 2016 [19]. A water level station located at the Yanshuixi Drainage was adopted to compare the simulated and observed results. The rainfall data were from the Central Weather Bureau and the Water Resources Agency, and the tidal data were from the Sicao Tide Station. The coefficient of efficiency (CE) of calibration and verification were 0.832 and 0.958 ; the root mean square error (RMSE) of calibration and verification were 0.28 and $0.21 \mathrm{~m}$. Those results showed the SOBEK model was relatively accurate for this study.

\subsection{Flood Damage Assessment System}

The Flood Damage Assessment System was used to estimate direct and indirect flood losses for four sectors: (1) Industrial and commercial; (2) Residential; (3) Agricultural; and (4) Public facilities. The direct loss for flooding in industrial and commercial areas was calculated through a questionnaire survey which was conducted in four areas of Taoyuan city, Taichung city, Kaohsiung city and Yilan County [30]. The survey results were analyzed to construct the flood depth-damage curves for the industrial and commercial sector. A statistical analysis was used to identify the major factors for regional adjustment in other areas in Taiwan. The industrial and commercial loss curves of the four areas were adjusted in accordance with factors identified, and the curves for other areas in Taiwan were acquired. The direct loss of flooding in industrial and commercial sector was divided into four categories: manufacturing, service, wholesale, and retail trade. The direct loss per flooded area for the four categories in Tainan City are shown in Table 2.

Table 2. Direct flood loss assessment equations in various categories of industry and commerce for Tainan City $\left(\mathrm{NT} \$ / \mathrm{m}^{2}\right)$.

\begin{tabular}{ccccc}
\hline Flooding Depth $(\mathbf{m})$ & $\mathbf{0 . 5}-\mathbf{1 . 0}$ & $\mathbf{1 . 0 - 2 . 0}$ & $\mathbf{2 . 0 - 3 . 0}$ & $>\mathbf{3 . 0}$ \\
\hline Loss of manufacturing & 0 & 1363 & 1696 & 4603 \\
Loss of service industry & 0 & 818 & 1514 & $\mathbf{2 8 1 6}$ \\
Loss of wholesale industry & 0 & 1181 & 1938 & 4936 \\
Loss of retail trade & 0 & 1181 & 2210 & 4451 \\
\hline
\end{tabular}

The direct loss for residential sector was obtained by the synthetic curve method. Residential sector has two kinds of flood loss curves, which are for apartment houses and individual houses. To construct the synthetic curve for residential flooding loss, the first step was to collect the data from the household ownership of modern home equipment in counties or cities to frame a typical home equipment template. Then, the survey of market prices for the equipment and location height of the equipment along with the flooding depth of the equipment and the relationship between the loss was conducted. The flood loss curves of apartment houses and individual houses for counties and cities in Taiwan can then be obtained. The direct flood loss estimation equations of Tainan City is shown in Table 3. The direct loss curves of flooding for residential sector is drown in Figure 3. 
Table 3. Direct flood loss estimation equations of various land use types for Tainan City.

\begin{tabular}{ccc}
\hline Land Use Type & Category & Flood Loss Curve \\
\hline \multirow{2}{*}{ Residence } & Apartment house & $L=142,150 \times D-29,365 \times D^{2}+2148 \times D^{3}$ \\
& Individual house & $L=18,807 \times D+151,230 \times D^{2}-186,500 \times D^{3}+$ \\
& $96,871 \times D^{4}-23,089 \times D^{5}+2062 \times D^{6}$ \\
\hline \multirow{2}{*}{ Agriculture } & Fish farming & $L=464,160 \times A$ \\
& Upland & $L=36,767 \times A$ \\
& Paddy & $L=30,614 \times A$ \\
Public facilities & Fruits & $L=133,736 \times A$ \\
\hline
\end{tabular}

$L$ : Direct flood loss (NT\$); $D$ : Flooding depth (m); A: Flooded area (ha).

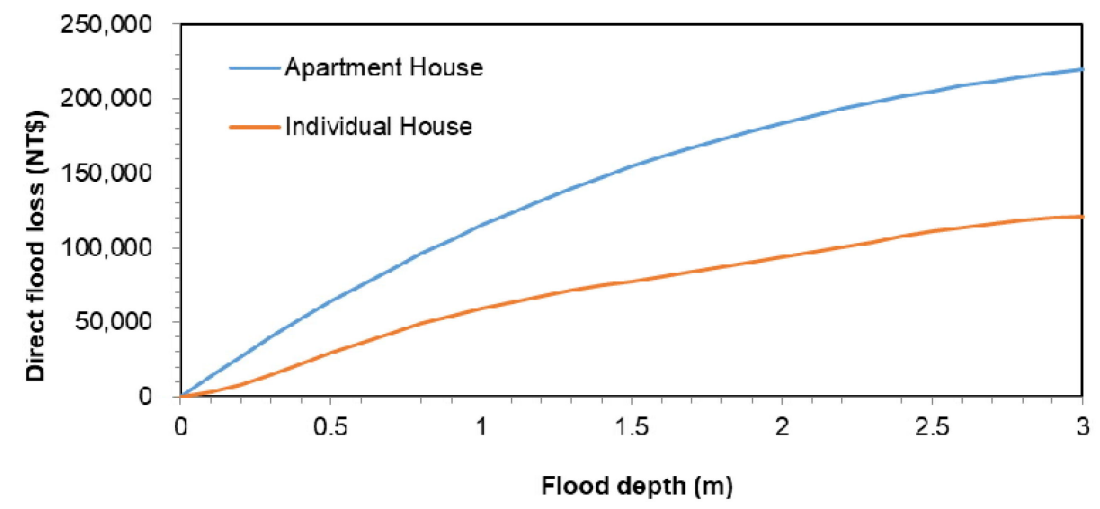

Figure 3. Direct loss curves of flooding for residential sector for Tainan City.

The public works rehabilitation data of the Public Construction Commission, Executive Yuan along with flooding areas corresponding to typhoons and flood disasters were referenced to establish the direct loss from flooding damage for public facilities. The direct loss was based on the relationship curves between flooding areas and loss value of public facilities. The direct loss of flooding for public facilities is estimated in unit area, as shown in Table 3.

The direct loss from flooding in agriculture was calculated through the collection of data relevant to the damage situation of the crops recorded in the Annual Statistics Report in Agriculture by the Council of Agriculture, Executive Yuan. The data of flooding damage were selected from various agricultural damages, and the agricultural loss corresponding to the damage year was converted to the present value according to the price indexes. The relationships between flooding areas and losses for upland, paddy cropping as well as fruits were established. The information on the direct loss of fish farming was collected from fish farms for the corresponding typhoons and floods recorded by the Fisheries Agency, Council of Agriculture, Executive Yuan. Analyses of the relationship between flooding area and loss value amount were conducted. The direct loss of flooding in agriculture is divided into four categories: fish farming, upland, paddy and fruits. These flooding losses are estimated on unit area flooded, as shown in Table 3. Relationships between direct flood loss and flooded area for agriculture and public facilities are shown in Figure 4. 


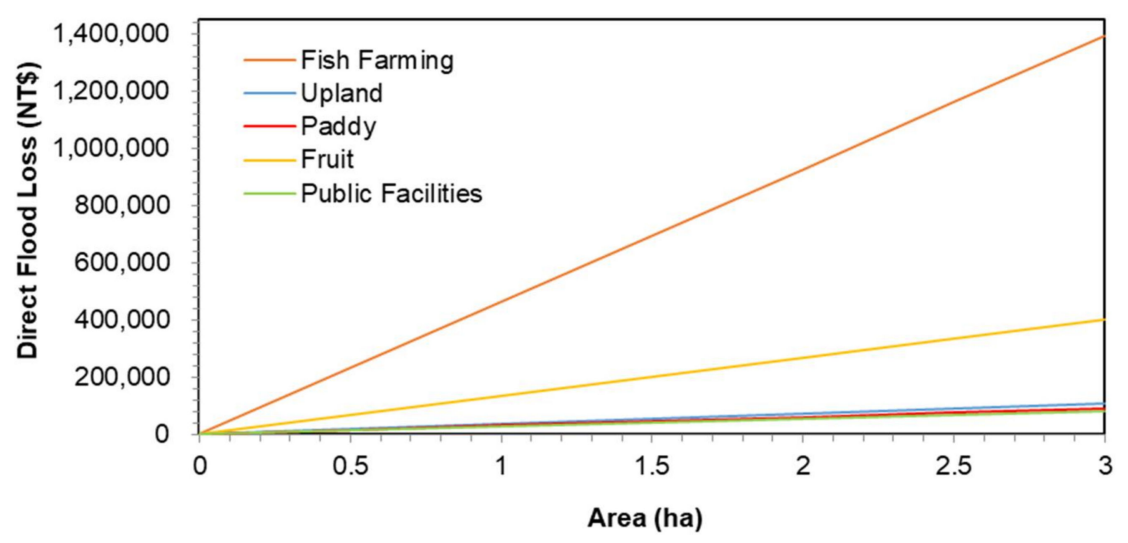

Figure 4. Relationship between direct loss of flooding and area for agriculture and public facilities for Tainan City.

The direct loss estimation method was mainly based on GIS software overlay analysis. The flood potential maps of various return periods were nested within the socio-economic layers of the study area. The flooded areas including residential, industrial, and agricultural land as well as flooded public facilities were analyzed. Flooding loss estimations for various sectors were then obtained by using the established loss curve models. Summing up all sectors led to the total flood loss.

Indirect losses were estimated using the industry-related model. As different industries and commerce are linked together, this linkage may break due to flooding and it can cause losses upstream and downstream of the links. To assess the indirect losses caused by flooding, they were analyzed using an industry-related model of 52 industry types in Taiwan. The model of industrial association coefficients was based on information published by the Directorate-General of Budget, Accounting and Statistics, Executive Yuan [31].

In this study, the expected annual damage (EAD) assessment was also estimated and the assessment is described in the following. $D(p, A)$ denotes the damage which occurs at the event with probability $p$ (the inverse of the return period) at the area $A$. The EAD can be expressed as [21,22]:

$$
\mathrm{EAD}=\int_{p} \int_{A} D(p, A) d A d p
$$

The integral is not easily solved for all return periods. Therefore, some approximation must be conducted to calculate the EAD. Several different methods for numerical integration exist; however, the trapezoidal rule is often used, leading to the following equation:

$$
\mathrm{EAD}=\sum_{i}^{n} \Delta P_{i} \cdot T L\left(P_{i}\right)
$$

in which $n$ is chosen so that all relevant return periods are covered from negligible cost of quite frequent events to very rare events. $T L\left(P_{i}\right)$ is the total loss for the event with probability $P_{i}$ at the area of interest. $\Delta P_{i}$ is a stepwise increment of exceedance probability and it is expressed in the following:

$$
\Delta P_{i}=\frac{1}{2}\left[\left(P_{i-1}-P_{i}\right)+\left(P_{i}-P_{i+1}\right)\right]
$$

The use of a stepwise linear relation between the return period and the damage loss enables only a few simulations and corresponds to losses, and can be carried out with a reasonable approximation. 


\section{Results and Discussion}

\subsection{Design Rainfall}

Taiwan is located in the western North Pacific-East Asian (WNP-EA) sector and its precipitation mainly comes from the Asian monsoon and typhoon systems [37,38]. Wu et al. investigated the statistical characteristics of extreme hourly precipitation over Taiwan during 2003-2012. All the extreme precipitation records were classified into four types: tropical cyclones (TCs), fronts, weak-synoptic forcing, and vortex/shear line types. Three-quarters of the total records resulted from TC type, while the front and weak-synoptic forcing types are comparable (9-13\%). The TCs occur over a longer duration time $(>12 \mathrm{~h})$ with a symmetrical evolution of hourly rainfall intensity. The front type and weak-synoptic forcing type tends to have a shorter period $(<6 \mathrm{~h})$ with a slightly asymmetrical evolution of hourly rainfall intensity [39]. Univariate analysis presents the inconvenience as it is hard to design realistic synthetic meteo-hydraulic events with more than one variable. The joint probability of a long storm duration and low intensity would probably differ from another one with a short storm duration, but with high intensity. A univariate model cannot consider these kinds of interactions among variables. High intensity or high duration can be considered independently, but not both variables in a dependent manner. This limitation harnesses how to build reliable synthetic events with univariate models. Multivariate statistical models can overcome this hindrance. For instance, copulas can be used for defining dependence structures for meteo-hydraulic events [40,41]. However, from the perspective of engineering design, the volume of detention basin, a key factor for engineering design, is dominated by the amount of design rainfall. For the security of the development zone, the Water Resources Agency, MOEA, adopted $24 \mathrm{~h}$ as the storm duration [33]. The rainfall hydrograph of 100-year return period is shown in Figure 5.

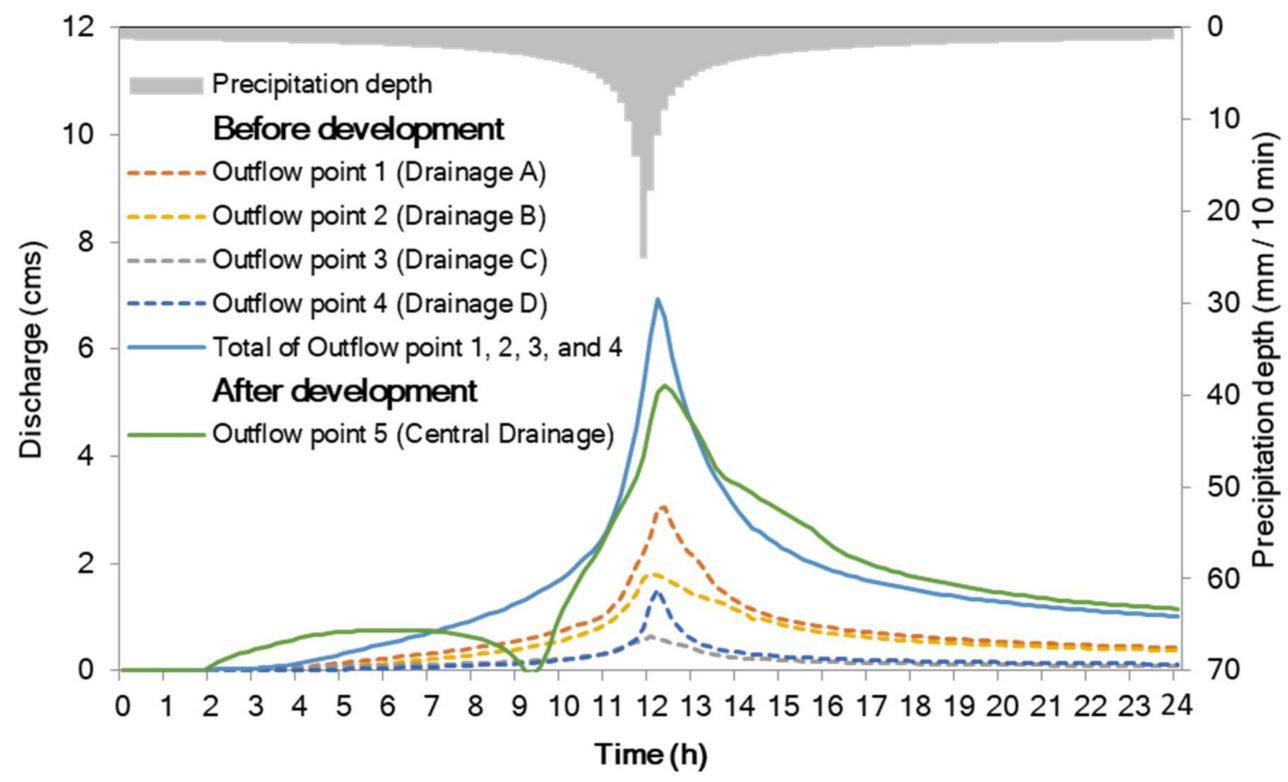

Figure 5. The outflow hydrograph of 100-year return period before and after land development.

\subsection{Peak Outflows before and after Development}

With 100-year return period rainfall, the outflow hydrograph of Outflow point 1 (Drainage A), Outflow point 2 (Drainage B), Outflow point 3 (Drainage C), and Outflow point 4 (Drainage D) before land development are shown in Figure 5, where flow of these four drainages increased or decreased in accordance with the volume of rainfall. The peak flow rates of Drainages A, B, C, and D in the first 13 $\mathrm{h}$ were found to be $3.05,1.81,0.64$, and $1.51 \mathrm{~m}^{3} / \mathrm{s}(\mathrm{cms})$, respectively. The peak flow rate of the overall outflow in the development zone was $6.92 \mathrm{cms}$. 
After land development, the surface runoff in the development area would be collected through the drainage system, then it would be concentrated into the Central Drainage, and finally drained to the Yanshuixi Drainage through Drainage F. Under a 100-year return period rainfall, the outflow hydrograph of Outflow point 5 (Central Drainage) is shown in Figure 5. Compared with the outflow hydrograph prior to development, it can be found that the flow after development was larger than before the development in the first 1-7 h. This was due to the detention basin in which the off-stream design was adopted, and the outflow in the development zone in the first $1-4 \mathrm{~h}$ was discharged directly into Drainage F. At the fifth hour, the flow of Central Drainage would be diverted to the detention basin when the water level of the Central Drainage was higher than the height of the lateral weir $(1.38 \mathrm{~m})$ of the detention basin. In the first 9-10 h, the outflow volume in development zone dropped suddenly or even the phenomenon of countercurrent was presented. That was because, although the water level of the Central Drainage continued to rise with increasing rainfall, it also continued to be diverted to the detention basin. At this time, the water level of Drainage F also raised up $(1.641 \mathrm{~m})$ with the increase of rainfall, even higher than the water level $(1.636 \mathrm{~m})$ of the Central Drainage, causing the Central Drainage flow not being able to be discharged. After the 11th hour, the Central Drainage flow also increased gradually with the increase in rainfall, and it reached the peak flow of $5.29 \mathrm{cms}$ in the 13th hour.

The peak outflow rate of various return periods before and after land development are shown in Figure 6 . With various return periods, peak outflow rates after development were smaller than those before the development, indicating the detention basin was able to effectively reduce the peak outflow rate arising from land development.

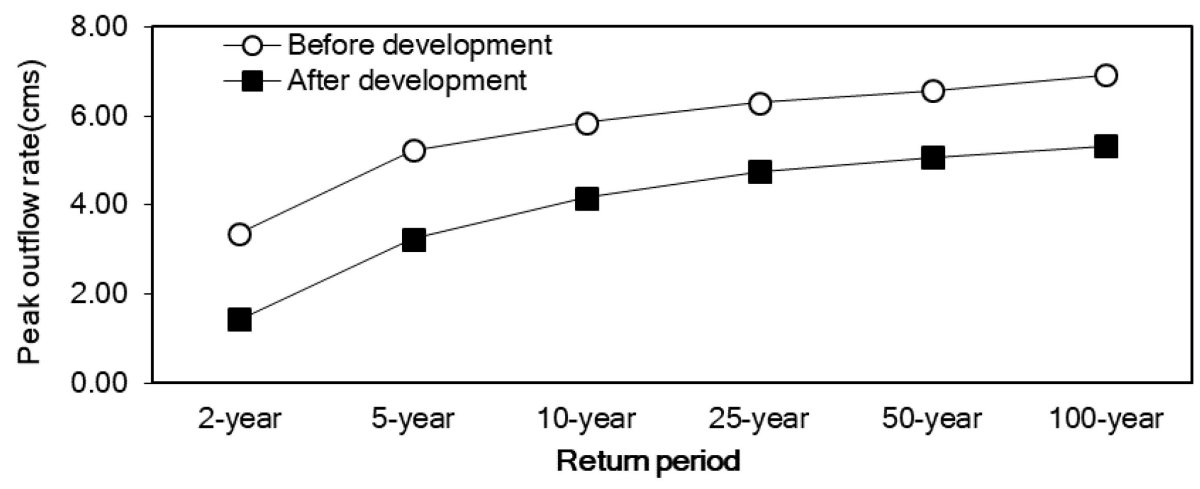

Figure 6. The peak outflow rate comparison of various return periods before and after land development.

\subsection{Analysis of Flooding Potential before and after Land Development}

The flooded area and the average flooding depth for various return periods are shown in Table 4 . The flooded area before and after land development under 50-year and 100-year return period rainfalls are shown in Figure 7. Under 100-year return period rainfall, the flooded area in the development zone before development was 14.24 ha and the average flooding depth was $0.607 \mathrm{~m}$. The flooded area in the southern area of the development zone was 20.8 ha and the average flooding depth was $0.747 \mathrm{~m}$. The water stages of the Yanshuixi Drainages were lower than the levees, and the overflow of the Yanshuixi Drainages did not occur. The stage of Drainage F was higher than that of the Yanshuixi Drainage. The flood of the Yanshuixi Drainages did not flow into the area through the Drainage F. The flood was from the surface runoff at the area. The limited flow capacities of the drainages resulted in flooding. The surface elevation was about 0.4 to $3.4 \mathrm{~m}$ in the development zone and the southern areas before land development were mostly fish farms except some buildings. As a result, floods accumulate frequently during heavy rain periods. 
The development zone used filling method to elevate the surface to $2.63-3.37 \mathrm{~m}$, while its southern area retained its original land usage. Therefore, the surface of the development zone was higher than that of the southern area. Under 100-year return period, there was no flooded area, the average flooding depth was higher than $0.30 \mathrm{~m}$ in the development zone, while the flooded area in its southern area was 20.64 hectares and the average flooding depth was $0.786 \mathrm{~m}$. After development, the stage of Drainage F was higher than that of the Yanshuixi Drainage. The flood of the Yanshuixi Drainages did not flow into the area through the Drainage F. The flood was from the surface runoff at the area. The limited flow capacities of the Drainages B, C, and D resulted in flooding.

In Figure 8, flooded areas and average flooding depths before development are larger than those after development. In Figure 9, flooded areas and average flooding depths before development are almost smaller than those after development. After land development, the flood risk of the development zone decreased. Because the elevation in the development zone was raised by adopting a filling method, and a complete drainage system and a detention basin were built in the development zone, flood risk in the southern area of the development zone also increased.

Before development, most of the development zone was fish pools, having the function of storing floodwater during storms and typhoons. However, these fish pools have been filled with soil due to land development. The detention basin constructed in it still has the function of storing floodwater, and, theoretically, the flood risk should not be transferred to the southern area of the development zone. However, it still shows a phenomenon of flood risk transfer. This is because, prior to development, there were four drainages that discharged runoff: Drainage $C$ and $D$ were flowing through Drainage F and then disembogued to Yanshuixi Drainage (Figure 1). With 100-year return period rainfall, the peak flow rate of Drainage C and D disemboguing into Drainage F was $2.11 \mathrm{cms}$ (Figure 2). The peak flow rate of Rainwater Sewer II was $7.60 \mathrm{cms}$, and the peak flow after the confluence was less than the flow capacity of Drainage F of $10.15 \mathrm{cms}$. After land development, all surface runoff flowed through the Central Drainage, with a peak flow rate of $5.29 \mathrm{cms}$. The peak flow rate of Rainfall Sewer II was $7.60 \mathrm{cms}$, and the peak flow after both confluence was greater than the flow capacity of Drainage F of $10.15 \mathrm{cms}$. Therefore, the overflow that occurred in Drainage F resulted in more intensified flooding in the southern area of the development zone. On the other hand, the overflow that occurred in Drainage $\mathrm{B}$ resulted in more mitigated flooding due to the diversion in the upstream. However, the overall risk of flooding increased.

Table 4. Flooded area and the average flooding depths of various return periods before and after land development.

\begin{tabular}{ccccccccc}
\hline \multirow{2}{*}{$\begin{array}{c}\text { Return Period } \\
\text { (Year) }\end{array}$} & \multicolumn{4}{c}{ Development Zone } & \multicolumn{3}{c}{ Southern Area of Development Zone } \\
\cline { 2 - 8 } & Flooded Area ${ }^{\text {a }}$ (ha) & \multicolumn{2}{c}{$\begin{array}{c}\text { Average Flooding } \\
\text { Depth (m) }\end{array}$} & \multicolumn{2}{c}{$\begin{array}{c}\text { Flooded Area } \\
\text { (ha) }\end{array}$} & $\begin{array}{c}\text { Average Flooding } \\
\text { Depth (m) }\end{array}$ \\
\cline { 2 - 9 } & $\mathbf{B D}^{\mathbf{b}}$ & AD $^{\mathbf{c}}$ & BD & AD & BD & AD & BD & AD \\
\hline 2 & 0 & 0 & 0 & 0 & 0.32 & 0.32 & 0.320 & 0.391 \\
5 & 3.68 & 0 & 0.484 & 0 & 4.80 & 5.76 & 0.528 & 0.565 \\
10 & 4.64 & 0 & 0.570 & 0 & 9.92 & 11.36 & 0.702 & 0.702 \\
25 & 7.36 & 0 & 0.546 & 0 & 15.04 & 16.32 & 0.724 & 0.724 \\
50 & 9.76 & 0 & 0.570 & 0 & 17.60 & 18.40 & 0.735 & 0.768 \\
100 & 14.24 & 0 & 0.607 & 0 & 20.80 & 20.64 & 0.747 & 0.786 \\
\hline
\end{tabular}

${ }^{\mathrm{a}}$ : The depth of flooding is greater than $0.3 \mathrm{~m}^{\mathrm{b}}{ }^{\text {: }}$ Before development; ${ }^{\mathrm{c}}$ : After development. 


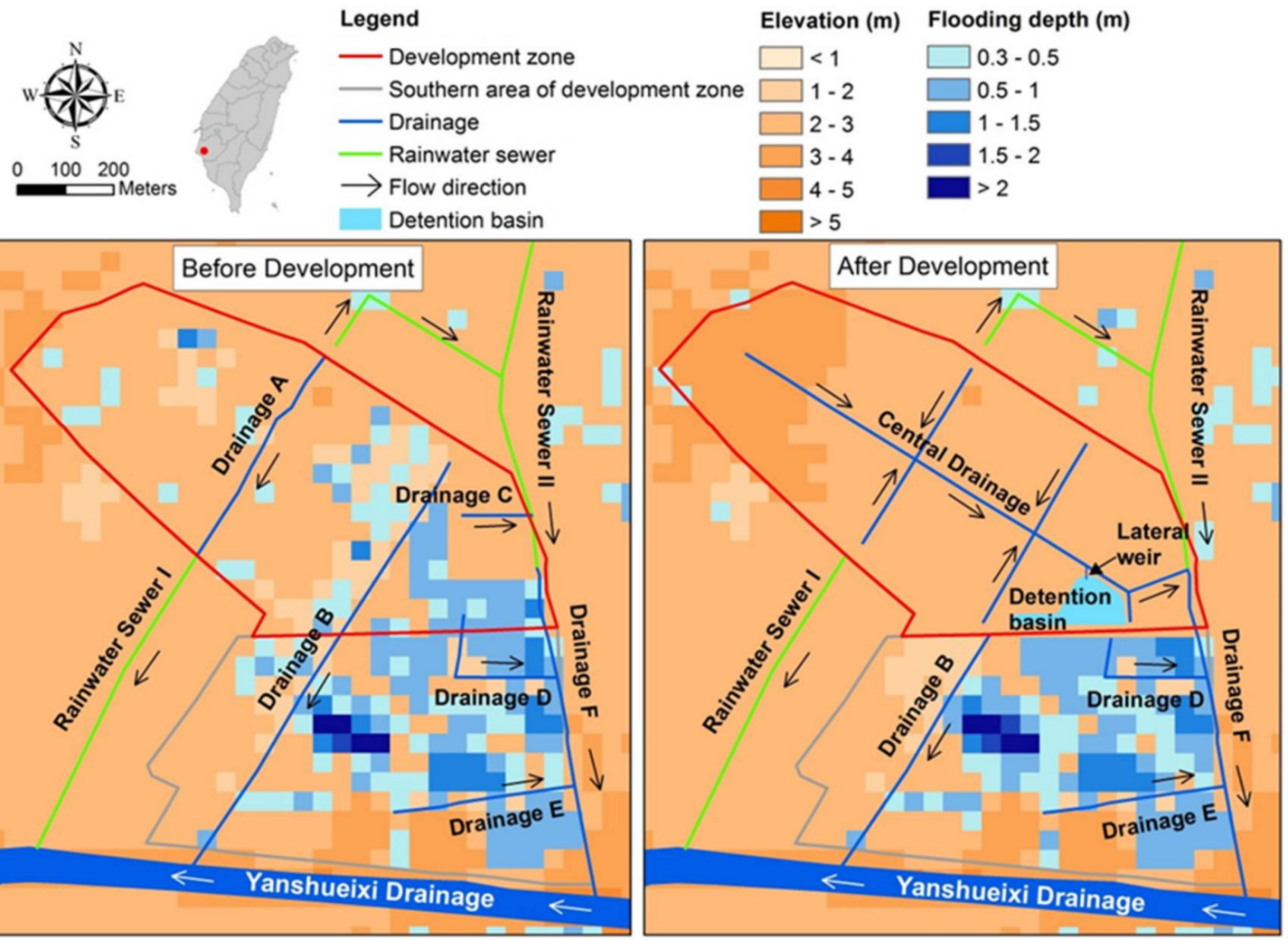

(A) 50-year return period
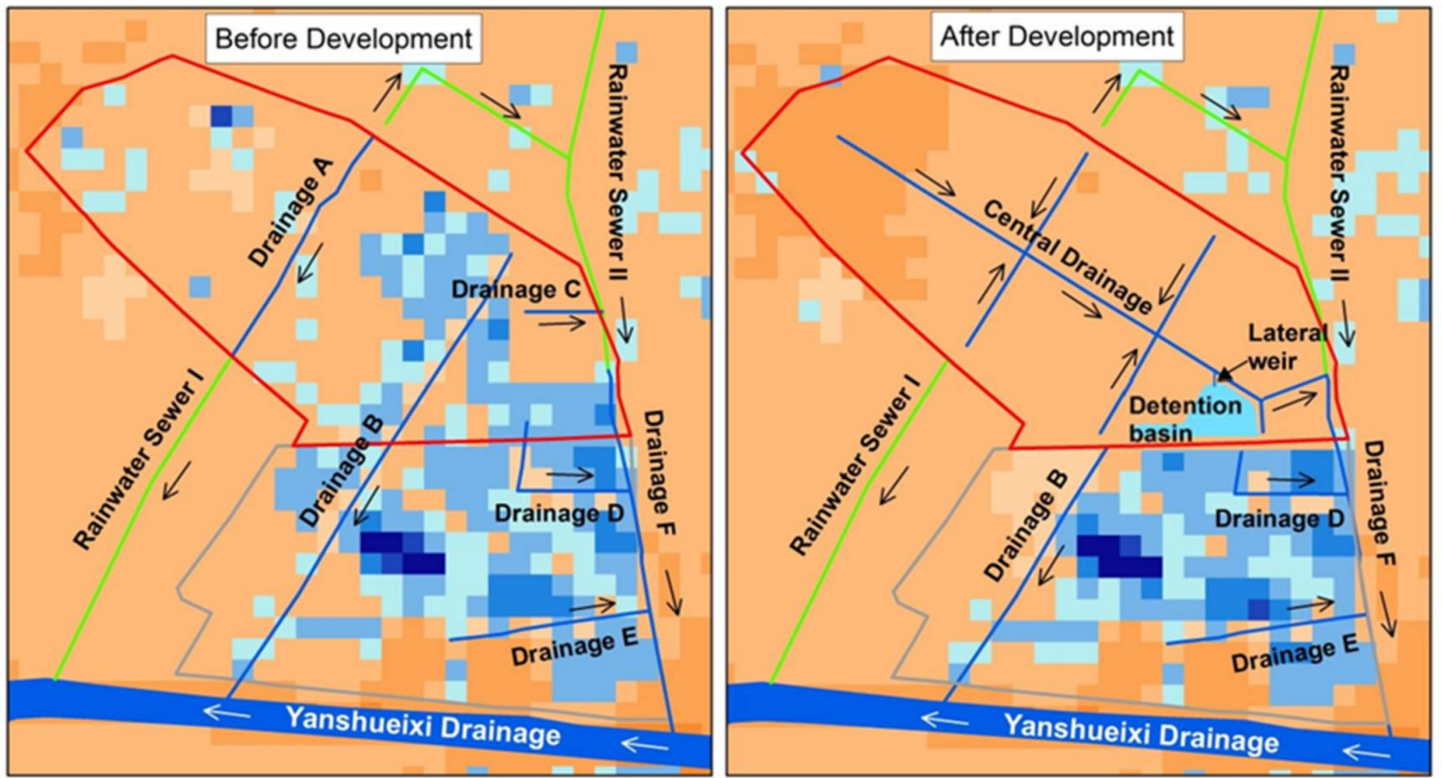

(B) 100-year return period

Figure 7. (A) The flooding range maps of 50-year return periods before and after land development. (B) The flooding range maps of 100-year return periods before and after land development. 

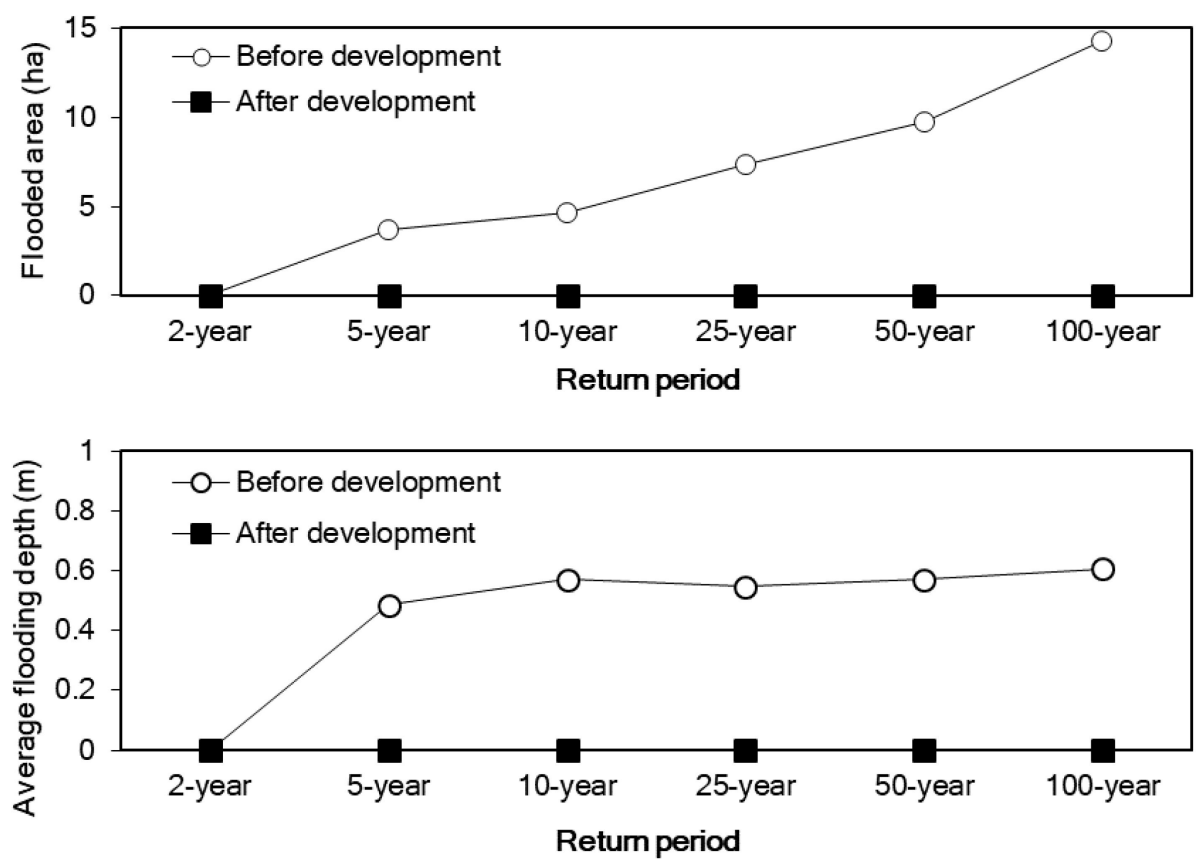

Figure 8. Comparison of flooding range and average flooding depth of various return periods before and after land development in development zone.
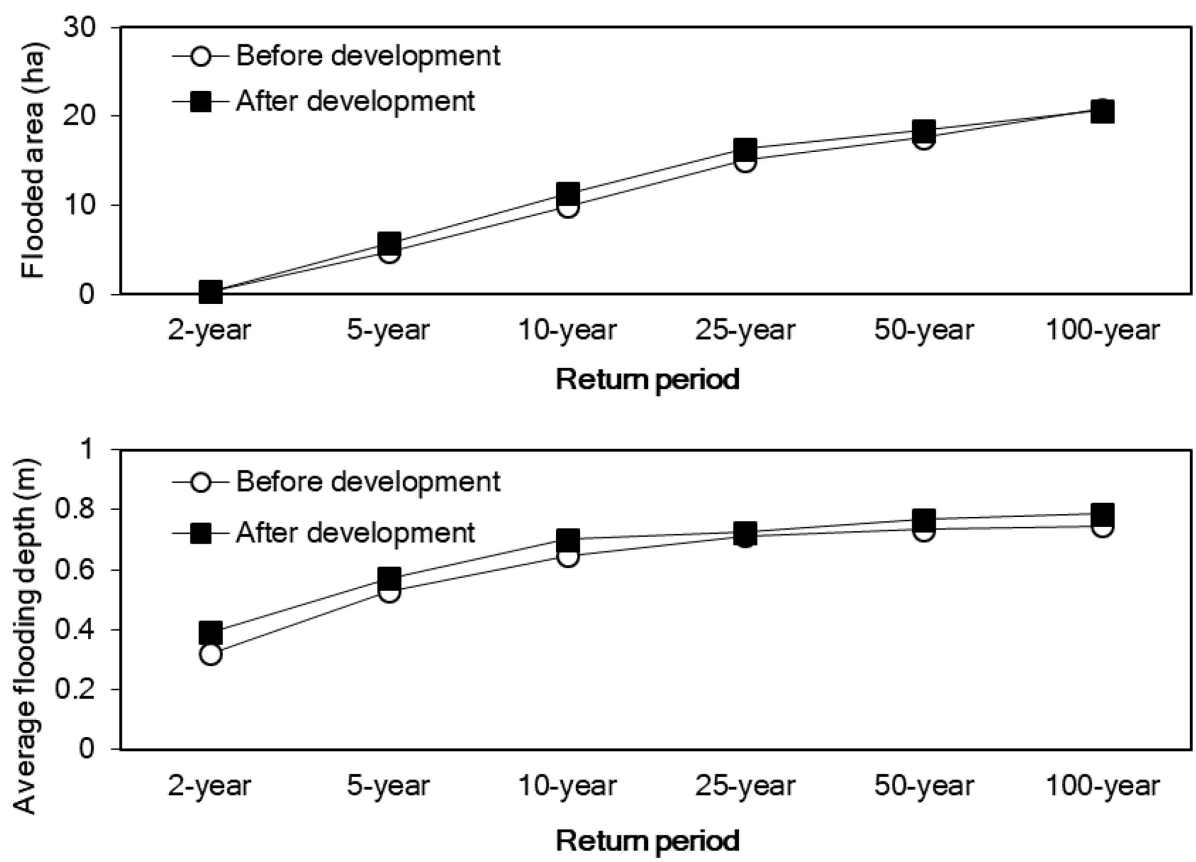

Figure 9. Comparison of flooding range and average flooding depth of various return periods before and after land development in the southern area of the development zone.

\subsection{Evaluation of Economic Losses before and after Land Development}

Based on the results of flooding area of various return periods before and after land development, the Flood Damage Assessment System calculated the flood losses for the corresponding return periods. Figure 10 shows the direct flood loss maps of 50-year and 100-year return periods. There are six simulations for various exceedance probabilities in Table 5 and the corresponding return periods are 2, $5,10,25,50$ and 100 years. The index $i$ for calculation in Equations (11) and (12) was then limited to 
from 1 to 6. For example, $\Delta \mathrm{P}_{2}=\left[\left(\mathrm{P}_{1}-\mathrm{P}_{2}\right)+\left(\mathrm{P}_{2}-\mathrm{P}_{3}\right)\right] / 2=0.2$. However, for quite frequent events (return period $=1$ ) and very rare events (return period $=\infty$ ), the exceedance probabilities were set to be 1 and 0 , and $\Delta \mathrm{P}_{1}=0.65$ as well as $\Delta \mathrm{P}_{6}=0.015$, respectively.

Table 5 shows that the longer the return period is, the higher the flood loss is. In addition, in the past when the indirect loss was not estimated by the industry-related model, the indirect loss was usually estimated at about $40-50 \%$ of the direct loss [42]. Table 5 shows that the ratio of indirect loss to direct loss is about 1.64-1.83, both before and after development. The indirect losses are higher compared with percentage estimations used in the past. Due to links between industries, when an industry is disrupted by the flooding, it might cause both industrial and commercial losses from the upstream and downstream. This study case showed that the indirect loss might be higher than the direct loss, a relevance that should not be overlooked.

Table 5 displays the EADs before and after land development in the southern area of the development zone. The EADs before and after land development were NT\$ 6.38 million and NT\$ 7.39 million showing that the EAD was increased by NT\$ 1.01 million after land development. It showed that the amount increased for the EAD was caused by the flood risk transferring due to land development.

There are six simulations for various exceedance probabilities in Table 5 and the corresponding return periods are 2, 5, 10, 25, 50 and 100 years. The index $i$ for calculation in Equations (11) and (12) was then limited to from 1 to 6 . For example, $\Delta P_{2}=\left[\left(P_{1}-P_{2}\right)+\left(P_{2}-P_{3}\right)\right] / 2=0.2$. However, for quite frequent events (return period $=1$ ) and very rare events (return period $=\infty$ ), the exceedance probabilities were set to be 1 and 0 , and $\Delta P_{1}=0.65$ as well as $\Delta P_{6}=0.015$, respectively.

Table 5 shows that the longer the return period is, the higher the flood loss is. In addition, in the past when the indirect loss was not estimated by the industry-related model, the indirect loss was usually estimated at about $40-50 \%$ of the direct loss [42]. Table 5 shows that the ratio of indirect loss to direct loss is about 1.64-1.83, both before and after development. The indirect losses are higher compared with percentage estimations used in the past. Due to links between industries, when an industry is disrupted by the flooding, it might cause both industrial and commercial losses from the upstream and downstream. This study case showed that the indirect loss might be higher than the direct loss, a relevance that should not be overlooked.

Table 5. Flooded area and the average flooding depths of various return periods before and after land development.

\begin{tabular}{|c|c|c|c|c|c|c|c|c|c|c|}
\hline \multirow{2}{*}{$\begin{array}{l}\text { Return } \\
\text { Period } \\
\text { (Year) }\end{array}$} & \multirow{2}{*}{$\begin{array}{l}\text { Probability of } \\
\text { Exceedance } \\
\text { (P) }\end{array}$} & \multirow[t]{2}{*}{$\Delta \mathbf{P}$} & \multicolumn{4}{|c|}{$\begin{array}{l}\text { Expected Annual Damage before Land } \\
\text { Development (NT\$ 1000) }\end{array}$} & \multicolumn{4}{|c|}{$\begin{array}{c}\text { Expected Annual Damage after Land } \\
\text { Development (NT\$ 1000) }\end{array}$} \\
\hline & & & $\begin{array}{c}\text { Direct } \\
\text { Loss (L) }\end{array}$ & $\begin{array}{l}\text { Indirect } \\
\text { Loss (I) }\end{array}$ & $\begin{array}{l}\text { Total Loss } \\
(\mathrm{TL}=\mathrm{L}+\mathrm{I})\end{array}$ & $\Delta \mathbf{P} \times \mathbf{T L}$ & $\begin{array}{c}\text { Direct } \\
\text { Loss (L) }\end{array}$ & $\begin{array}{l}\text { Indirect } \\
\text { Loss (I) }\end{array}$ & $\begin{array}{l}\text { Total Loss } \\
(\mathrm{TL}=\mathrm{L}+\mathrm{I})\end{array}$ & $\Delta \mathbf{P} \times \mathbf{T L}$ \\
\hline 2 & 0.50 & 0.650 & 120 & 220 & 340 & 221 & 120 & 220 & 340 & 221 \\
\hline 5 & 0.20 & 0.200 & 3080 & 5190 & 8270 & 1654 & 4150 & 6990 & 11,140 & 2228 \\
\hline 10 & 0.10 & 0.080 & 8100 & 13,380 & 21,480 & 1718 & 9450 & 15,620 & 25,070 & 2006 \\
\hline 25 & 0.04 & 0.040 & 13,010 & 21,470 & 34,480 & 1379 & 13,850 & 22,880 & 36,730 & 1469 \\
\hline 50 & 0.02 & 0.015 & 15,550 & 25,610 & 41,160 & 617 & 17,180 & 28,300 & 45,480 & 682 \\
\hline 100 & 0.01 & 0.015 & 20,040 & 32,850 & 52,890 & 793 & 19,780 & 32,400 & 52,180 & 783 \\
\hline \multicolumn{3}{|c|}{ EAD (NT\$ 1000/year) } & \multicolumn{4}{|c|}{6382} & \multicolumn{4}{|c|}{7389} \\
\hline \multicolumn{3}{|c|}{$\begin{array}{l}\text { The increased EAD after land } \\
\text { development (NT\$ 1000/year) }\end{array}$} & \multicolumn{8}{|c|}{1007} \\
\hline
\end{tabular}




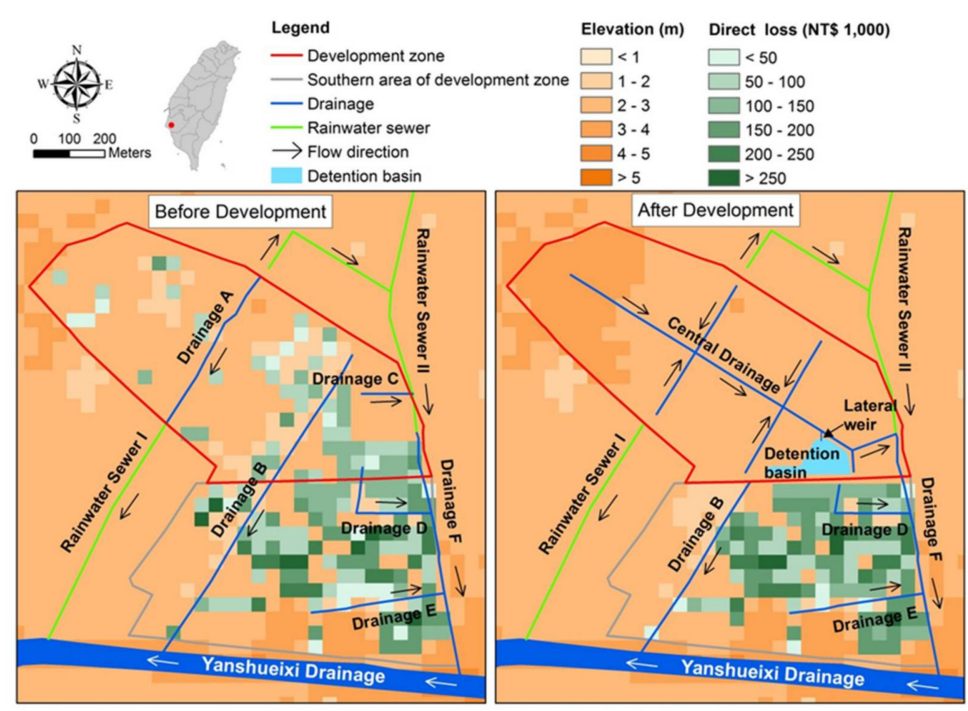

(A) 50-year return period

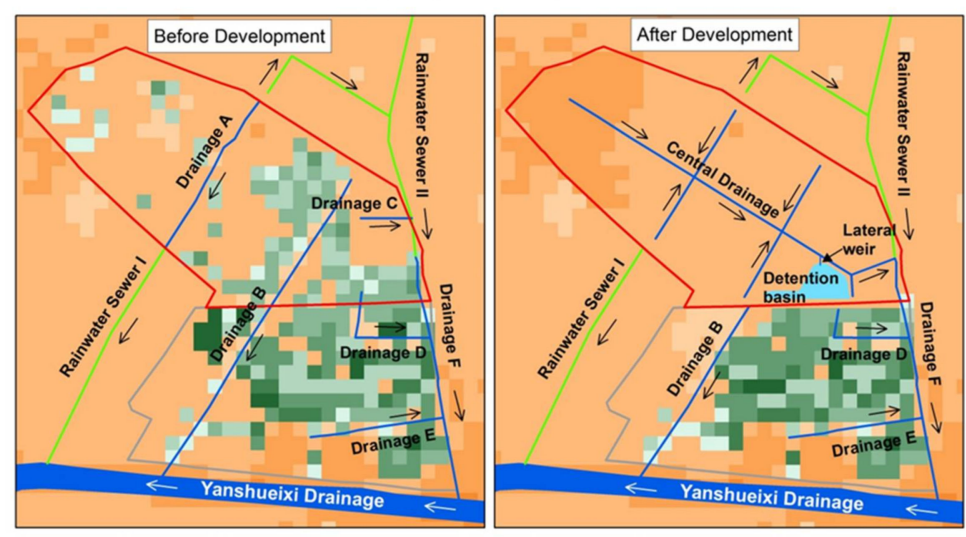

(B) 100-year return period

Figure 10. (A) The direct flood loss maps of 50-year return periods before and after land development. (B) The direct flood loss maps of 100-year return periods before and after land development.

\subsection{Flood Risk Transfer Effect}

From the above research results, there are two effects of development in low-lying land using the filling method. One is because of the increased peak flow after land development which can be reduced through the detention basin. However, another effect is the transfer of flood risk. Reasons for flood risk transfer are as follows. (1) The low-lying areas that originally could accumulate floods have been filled up with soil for development, resulting in the disappearance of the original flooding storage space. This transfers the risk of flooding from the development zone to its surrounding areas. (2) This change of the existing decentralized drainage system in the development zone causes the transfer of flood risk to the surrounding areas.

Therefore, the ways to avoid the risks of flood hazard transfer caused by the development are as follows. (1) The best way is to avoid land development with a high flooding potential. The integration of flood risk management into spatial planning processes can reduce effectively the flood damages resulting from inappropriate land development [43]. (2) Second is to not use the filling method to change the original terrain in the low-lying land, and development to be conducted in accordance with the original terrain condition in order to reduce the flood risk transfer effect. (3) Third is to not change the subwatershed of the original drainage in the development zone but pay attention to the flow capacity of the connecting waterways between the exits of the development zone and the downstream river. 
Structural and non-structural measures can be implemented to mitigate the flood risk transfer effect on the surrounding area in the development zone. For structural measures, sewer system, detention basins, pumping stations, and LID methods are commonly adopted. For non-structural measures, people and authorities respond according to early warning systems [44]. For instance, in the flood-prone areas, flood gates for the buildings are set up to prevent flooding, and people evacuate to the second floors or neighboring shelters.

In addition, economic loss assessment for the land before and after development adopted in this study can be used by the land developers to calculate and estimate the amount of compensation for the land with flood damages. The methodology can also be applied to assess the damage from rainfall-induced, river-induced, and marine storm-surge induced flooding. The sensitivity analysis for the methodology proposed in this study will increase understanding of the relationships between input and output variables in a land development model, and this is also a research direction in the future.

\section{Conclusions}

The methodology developed in this study can assess the damage of flood risk transfer effect on surrounding areas arising from land development. The SOBEK model was used to simulate the flooding ranges of various return periods before and after land development. After land development, the flooding ranges in the development zone decreased; however, the flooding ranges in the southern area of the development zone increased. Because the elevation in the development zone was raised by adopting a filling method, and a complete drainage system and a detention basin were built in the development zone, the land development changed the original decentralized drainage system to centralized drainage system. This resulted that the peak outflow discharge in the Central Drainage was more than the flow capacity of the downstream channel and increased the flooding range in the southern area of the development zone. The Flood Damage Assessment System developed by the WRPI was used calculated the amount of losses before and after land development in the southern area of the development zone. Direct losses due to floods for industrial, commercial, residential, and agricultural lands as well as public facilities were calculated by the flood damage curves. Indirect losses were estimated using the industry-related model. The EAD of the southern area in the development zone was NT\$ 6.38 million before development, and the EAD was NT\$ 7.39 million after development. The increase for the EAD (NT\$1.01 million) was caused by the flood risk transferring due to land development.

Acknowledgments: The authors appreciate the editors and anonymous referees for their thoughtful comments and suggestions. The authors are grateful for the funding support of the Water Resources Agency, Ministry of Economic Affairs, Taiwan (grant numbers MOEAWRA1050134). The authors thank Wen-Tsun Fang for assisting in the revision of the manuscript. The authors thank Yung-Hsien Lin's assistance for the model simulation. The authors appreciate George Chih-Yu Chen for his assistance in the English editing.

Author Contributions: Song-Yue Yang wrote the paper and performed the experiments; Ming-Hsiu Chan performed the experiments; Che-Hao Chang built the model; and Ling-Fang Chang assessed the damage.

Conflicts of Interest: The authors declare no conflict of interest.

\section{References}

1. Coutu, G.W.; Vega, C. Impacts of landuse changes on runoff generation in the east branch of the brandywine creek watershed using a GIS-based hydrologic model. Middle States Geogr. 2007, 40, 142-149.

2. Panahi, A.; Alijani, B.; Mohammadi, H. The effect of the land use/cover changes on the floods of the Madarsu Basin of Northeastern Iran. J. Water Resour. Prot. 2010, 2, 373-379. [CrossRef]

3. Motevalli, S.; Hosseinzadeh, M.; Esmaili, R.; Derafshi, K.; Gharehchahi, S. Assessing the effects of land use change on hydrologic balance of Kan watershed using SCS and HEC-HMS hydrological models-Tehran, Iran. Aust. J. Basic Appl. Sci. 2012, 6, 510-519.

4. Kang, I.S.; Park, J.I.; Singh, V.P. Effect of urbanization on runoff characteristics of the On-Cheon Stream watershed in Pusan, Korea. Hydrol. Process. 1998, 12, 351-363. [CrossRef] 
5. Yu, P.; Wang, Y.; Kuo, C.-C. Effects of land-use change on runoff response in the ungauged Ta-Chou basin, Taiwan. Int. Assoc. Hydrol. Sci. Publ. 2003, 279, 162-170.

6. Shi, P.-J.; Yuan, Y.; Zheng, J.; Wang, J.-A.; Ge, Y.; Qiu, G.-Y. The effect of land use/cover change on surface runoff in Shenzhen region, China. Catena 2007, 69, 31-35. [CrossRef]

7. Yang, S.; Jung, W.; Han, W.; Chung, I. Impact of land-use changes on stream runoff in Jeju island, Korea. Afr. J. Agric. Res. 2012, 7, 6097-6109.

8. Nardi, F.; Annis, A.; Biscarini, C. On the impact of urbanization on flood hydrology of small ungauged basins: The case study of the Tiber river tributary network within the city of Rome. J. Flood Risk Manag. 2018, 11 (Suppl. 2), s594-s603. [CrossRef]

9. Du, S.; Van Rompaey, A.; Shi, P.; Wang, J.A. A dual effect of urban expansion on flood risk in the pearl river delta (China) revealed by land-use scenarios and direct runoff simulation. Nat. Hazards 2015, 77, 111-128. [CrossRef]

10. Yao, L.; Wei, W.; Chen, L. How does imperviousness impact the urban rainfall-runoff process under various storm cases? Ecol. Indic. 2016, 60, 893-905. [CrossRef]

11. Miller, J.D.; Kim, H.; Kjeldsen, T.R.; Packman, J.; Grebby, S.; Dearden, R. Assessing the impact of urbanization on storm runoff in a peri-urban catchment using historical change in impervious cover. J. Hydrol. 2014, 515, 59-70. [CrossRef]

12. Clark County Regional Flood Control District (CCRFCD). Hydrologic Criteria and Drainage Manual; Clark County Regional Flood Control District: Clark County, NV, USA, 1999.

13. Urban Drainage and Flood Control District (UDFCD). Urban Storm Drainage Criteria Manual; Urban Drainage and Flood Control District: Denver, CO, USA, 2016; Volume 1-3.

14. Environment Agency (EA). Rainfall Runoff Management for Developments—Revision E; Environment Agency: Rotherham, UK, 2013.

15. Ministry of Economic Affairs (MOEA). Drainages Administration Regulation; Ministry of Economic Affairs: Taipei, Taiwan, 2016.

16. Guo, J.C. Preservation of watershed regime for low-impact development through detention. J. Hydrol. Eng. 2009, 15, 15-19. [CrossRef]

17. Chen, W.-B.; Liu, W.-C. Modeling flood inundation induced by river flow and storm surges over a river basin. Water 2014, 6, 3182-3199. [CrossRef]

18. Doong, D.-J.; Lo, W.; Vojinovic, Z.; Lee, W.-L.; Lee, S.-P. Development of a new generation of flood inundation maps-A case study of the coastal city of Tainan, Taiwan. Water 2016, 8, 521. [CrossRef]

19. Yang, S.-Y.; Chan, M.-H.; Chang, C.-H.; Hsu, C.-T. A case study of flood risk transfer effect caused by land development in flood-prone lowlands. Nat. Hazards 2018, 91, 863-878. [CrossRef]

20. Grigg, N.S. Water Resources Planning; Department of Energy: Oak Ridge, TN, USA, 1985.

21. Zhou, Q.; Mikkelsen, P.S.; Halsnæs, K.; Arnbjerg-Nielsen, K. Framework for economic pluvial flood risk assessment considering climate change effects and adaptation benefits. J. Hydrol. 2012, 414-415, 539-549. [CrossRef]

22. Olsen, A.S.; Zhou, Q.; Linde, J.J.; Arnbjerg-Nielsen, K. Comparing methods of calculating expected annual damage in urban pluvial flood risk assessments. Water 2015, 7, 255-270. [CrossRef]

23. Petak, W.J.; Atkisson, A.A. Natural Hazard Risk Assessment and Public Policy: Anticipating the Unexpected; Springer: Berlin, Germany, 1982.

24. Van der Sande, C. River Flood Damage Assessment Using IKONOS Imagery; European Commission; Joint Research Centre: Brussels, Belgium; Luxembourg, 2001.

25. Genovese, E. A Methodological Approach to Land Use-Based Flood Damage Assessment in Urban Areas: Prague Case Study; Technical EUR Reports, EUR 22497; EUR: Brussels, Belgium, 2006.

26. Handmer, J.W.; Reed, C.; Percovich, O. Disaster Loss Assessment: Guidelines; Department of Emergency Services: Melbourne, Australia, 2002.

27. Kang, J.-L.; Su, M.-D.; Chang, L.-F. Loss functions and framework for regional flood damage estimation in residential area. J. Mar. Sci. Technol. 2005, 13, 193-199.

28. Green, C.; Wierstra, E.; Penning, P.; van der Veen, A. Vulnerability refined: Analysing full flood impacts. In Floods Across Europe; Middelsex University Press: London, UK, 1994.

29. Du Plessis, L.; Viljoen, M. Calculation of the secondary effects of floods in the lower orange river area-A GIS approach. Water SA 1999, 25, 197-203. 
30. Chang, L.-F. Flood Damage Investigation and Analysis in Metropolitan Area; Water Resources Planning Institute, Water Resources Agency: Taichung, Taiwan, 2014.

31. Chang, L.-F. Study on Regional Adjustment Mechanism for Flood Damage and System Establishment; Water Resources Planning Institute, Water Resources Agency: Taichung, Taiwan, 2016.

32. Tainan City Government (TCG). Drainage Plan for the Caohu (i) Urban Land Readjustment Implementation by the Private Sector in Tainan; Tainan City Government: Tainan, Taiwan, 2014.

33. Ministry of Economic Affairs (MOEA). Calculation Method of Discharges and Volumes for Mitigation Facilities in Drainage Plan; Ministry of Economic Affairs: Taipei, Taiwan, 2017.

34. Lin, Z.-H. The Planning of Regulation and Environment Rehabilitation of Yanshuixi Drainage in Tainan Area; Water Resources Planning Institute, Water Resources Agency: Taichung, Taiwan, 2010.

35. Chow, V.; Maidment, D.; Mays, L. Applied Hydrology; McGraw-Hill: New York, NY, USA, 1988; 572p.

36. Deltares. Sobek User Manual; Deltares: Delft, The Netherlands, 2017.

37. Chou, C.; Huang, L.-F.; Tseng, L.; Tu, J.-Y.; Tan, P.-H. Annual cycle of rainfall in the western north pacific and east asian sector. J. Clim. 2009, 22, 2073-2094. [CrossRef]

38. Chen, J.-M.; Li, T.; Shih, C.-F. Tropical cyclone- and monsoon-induced rainfall variability in Taiwan. J. Clim. 2010, 23, 4107-4120. [CrossRef]

39. Wu, M.; Wu, C.-C.; Yen, T.-H.; Luo, Y. Synoptic analysis of extreme hourly precipitation in taiwan during 2003-12. Mon. Weather Rev. 2017, 145, 5123-5140. [CrossRef]

40. Wang, Y.; Li, C.; Liu, J.; Yu, F.; Qiu, Q.; Tian, J.; Zhang, M. Multivariate analysis of joint probability of different rainfall frequencies based on copulas. Water 2017, 9, 198. [CrossRef]

41. Lin-Ye, J.; García-León, M.; Gràcia, V.; Ortego, M.I.; Stanica, A.; Sánchez-Arcilla, A. Multivariate hybrid modelling of future wave-storms at the northwestern Black Sea. Water 2018, 10, 221. [CrossRef]

42. Grigg, N.S.; Helweg, O.J. State-of-the-art of estimating flood damage in urban areas. J. Am. Water Resour. Assoc. 1975, 11, 379-390. [CrossRef]

43. Herk, S.; Zevenbergen, C.; Rijke, J.; Ashley, R. Collaborative research to support transition towards integrating flood risk management in urban development. J. Flood Risk Manag. 2011, 4, 306-317. [CrossRef]

44. Jang, J.-H. An advanced method to apply multiple rainfall thresholds for urban flood warnings. Water 2015, 7,6056-6078. [CrossRef] 